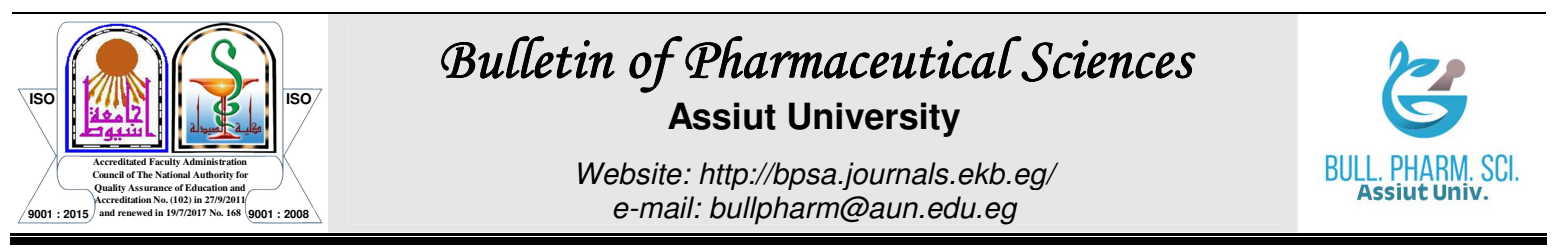

\title{
CHARACTERIZATION, IN-VITRO EVALUATION OF PROBIOTIC POTENTIAL AND ANTAGONISTIC ACTIVITY OF SELECTED LACTIC ACID BACTERIA STRAINS ISOLATED FROM NATURAL ORIGIN AGAINST SOME HUMAN PATHOGENS
}

\author{
Azza S. Zakaria*, Mervat A. Kassem, Mona S. El Far and Eva A. Edward \\ Department of Microbiology and Immunology, Faculty of Pharmacy, Alexandria University, \\ Alexandria, Egypt
}

\begin{abstract}
Probiotic bacteria have recently become popular for their health-related beneficial effects. In this study, 19 lactic acid bacteria were isolated from breast milk, dairy products, infant stool, vaginal swabs, fermented beverages, and fermented grapes. These isolates were evaluated for their tolerance to gastrointestinal conditions, hydrophobicity, auto-aggregation, and antimicrobial activity. Five isolates, belonging to Pediococcus spp. and Lactobacillus spp., showed potential probiotic features. These isolates were tested for the presence of virulence enzymes and for susceptibility to various antibiotics. The isolates were found to be non-hemolytic and lacked gelatinase and deoxyribonuclease enzymes, however, some antibiotic resistance genes were detected. To ensure the safety of the used probiotics, cell-free supernatants (CFS) of the promising candidates were prepared and its antimicrobial activity before and after neutralization was assessed against standard strains of Candida albicans, Gram-positive, and Gram-negative bacteria. The neutralization of the CFS significantly diminished the antibacterial and antifungal activities of probiotics. Using the time-kill assay, the combination of CFS of Lactiplantibacillus plantarum with gentamicin and ceftazidime was tested against Staphylococcus aureus and Escherichia coli clinical isolates. A significant reduction in log number of survivors was obtained with gentamicin against E. coli and with ceftazidime against both isolates. The anti-biofilm ability of the CFS of the selected probiotics was tested as well. Neutralized CFS caused 26-52\% inhibition of S. aureus isolate biofilm formation compared to the control. In conclusion, the five selected isolates could be considered promising probiotic candidates that can be used as biotherapeutics in case of bacterial infection.
\end{abstract}

\section{INTRODUCTION}

In the last decade, probiotic bacteria have become popular for their human health-related beneficial effects. Owing to the unceasingly expanding scientific research directing attention to probiotics' valuable health impact, the demand for new probiotic dietary supplements, as well as probiotic foodstuffs and beverages, has increased ${ }^{1 \& 2}$.

Probiotics are live micro-organisms that can exist as single or mixed cultures. They can confer advantageous health effects for the host if they are administered in adequate amounts ${ }^{3}$.
A great number of the previously identified probiotic bacteria, including Lactococcus spp., Lactobacillus spp., Streptococcus spp., Bifidobacteria spp., Enterococcus spp. and Pediococcus spp., originally belong to the lactic acid bacteria (LAB) genera. However, the most promising probiotic candidates are Lactobacillus spp. and Bifidobacteria spp. ${ }^{3}$.

Probiotic strains can be successfully isolated from various sources. Amongst the common sources of probiotics are dairy and dairy-related products, breast milk $^{4}$, and human vagina ${ }^{5}$. Numerous probiotic strains have been isolated from the human gut, as well as from

Received in 2/3/2021 \& Accepted in 30/3/2021 
the fecal samples of healthy adults and infants. Besides, non-dairy fermented substrates, such as fermented meat and fruits, represent a valuable source of probiotics ${ }^{4}$.

Many studies highlighted the significant effect of probiotics on human health. It is believed that they might help in reducing the incidence of cancer, as well as preventing coronary heart disease by controlling blood pressure and reducing the levels of serum cholesterol $^{1}$. Probiotics are also capable of ameliorating bacterial vaginosis by supporting the normal vaginal lactobacilli microbiota ${ }^{1}$. Moreover, they are reported to play a considerable role in augmenting the immune response, improving the functionality of the intestine, enhancing lactose metabolism, as well as diminishing the severity of rheumatoid arthritis, inflammatory bowel disease, and irritable bowel syndrome ${ }^{1 \& 3}$.

A real probiotic strain should possess specific desirable properties. Such properties include tolerance to bile toxicity and gastric acidity, proper adhesion to epithelial and mucosal surfaces, the capability of improving the host immune response, as well as the potential antimicrobial activity against various pathogens $^{1 \& 6}$. This activity has currently become one of the most significant features of promising probiotic candidates due to the widespread of antibiotic-resistant pathogens and the misuse of antibiotics. Thus, special attention has been paid to the utilization of probiotics and their antimicrobial metabolites, either alone or in combination with different antibiotics, for the treatment and prevention of various microbial infections as an alternative antimicrobial strategy ${ }^{2 \& 7}$.

In view of the current data, this study aimed at the isolation, identification and characterization of some LAB strains isolated from various natural sources, including dairy products, fermented grapes, breast milk, infant feces, vaginal swabs, and fermented beverages, to assess their potential as promising probiotic candidates. Moreover, the antimicrobial activity of such candidates, alone or in combination with antibiotics, against different pathogens was tested. The anti-biofilm ability of selected candidates to prevent formation of biofilms during the growth of pathogenic bacteria was evaluated as well.

\section{MATERIALS AND METHODS}

\section{Collection and isolation of microorganisms from natural sources}

A total of 47 samples were collected from different natural sources. Twenty-four samples were collected aseptically from healthy women's breast milk within 4-6 months of giving birth to healthy babies. The nipple and mammary areola of the breast were washed and wiped with sterile saline and about $5 \mathrm{~mL}$ of milk was collected in a sterile falcon manually or using a sterile breast pump ${ }^{2}$. Thirteen samples were taken from dairy products that were purchased from local vendors (3 curd samples, 7 yogurt samples, 2 household milk samples, and 1 soft cheese (Karish) sample). Three vaginal samples from healthy women of childbearing age, and 5 samples from fermented beverages ( 3 fermented sugarcane juice and 2 fermented carob juice samples) were obtained. One sample was taken from fermented grapes where $500 \mathrm{~g}$ of washed fresh grapes were fermented in $300 \mathrm{~mL}$ sterile distilled water and $100 \mathrm{~g}$ glucose in $1 \mathrm{~L}$ jar for 30 days in a relatively warm place. The jar was shaken for $30 \mathrm{~s}$ and left to stand for $5 \mathrm{mins}$ at room temperature, then the supernatant was collected from which the sample was taken. One sample was obtained from the feces of a healthy breastfed 4-month-old infant. The feces sample was collected in a sterile falcon, then approximately $1 \mathrm{~g}$ of the sample was homogenized with $5 \mathrm{~mL}$ sterile saline ${ }^{2}$.

All the obtained samples were 10 -fold serially diluted in sterile saline then $40 \mu \mathrm{L}$ from different dilutions were spread over deMan, Rogosa and Sharpe (MRS) agar plate and incubated aerobically at $37^{\circ} \mathrm{C}$ for $24-48 \mathrm{hrs}$ for the isolation of LAB.

\section{Characterization and identification of LAB isolates}

The tested isolates were streaked onto the surface of MRS agar plates containing $1 \%$ $\mathrm{CaCO}_{3}$ and incubated aerobically at $37^{\circ} \mathrm{C}$ for 24-48 hrs. Formation of a clear zone surrounding the colonies indicated the presence of acid producing bacteria ${ }^{8}$. LAB isolates were confirmed by being Gram-positive, catalase negative, non-endospore forming and nonmotile bacteria ${ }^{9}$. Promising isolates were further identified using the 16s rRNA 
sequencing ${ }^{10}$. The sequencing was conducted at GATC Biotech DNA sequence company, Germany. Primers used are listed in table 1.

\section{Survival of LAB isolates under conditions simulating the human gastrointestinal tract (GIT)}

Bacterial cells from $5 \mathrm{~mL}$ overnight cultures were harvested by centrifugation at $6000 \mathrm{~g}$ for $10 \mathrm{mins}$ at $4^{\circ} \mathrm{C}$. For the acid and pepsin tolerance tests, bacterial pellets were washed twice with phosphate buffer saline (PBS), $\mathrm{pH} 7.2$, then resuspended in $1 \mathrm{~mL}$ PBS solution, $\mathrm{pH} 3$, and/or $\mathrm{pH} 2$, either alone or containing pepsin $(3 \mathrm{mg} / \mathrm{mL})$ then incubated for $3 \mathrm{hrs}$ at $37^{\circ} \mathrm{C}^{11}$. For the bile and pancreatin tolerance tests, the pellets were resuspended in $1 \mathrm{~mL}$ PBS solution, $\mathrm{pH} 8$, containing $0.3 \%$ oxbile or $1 \mathrm{mg} / \mathrm{mL}$ pancreatin, respectively, then incubated at $37^{\circ} \mathrm{C}$ for $4 \mathrm{hrs}^{11 \& 12}$. To simulate the in-vivo conditions of gastric digestion, a volume of reconstituted skimmed milk (RSM) ( $11 \%$ solids, w/v) was added to PBS solution, $\mathrm{pH} 2$ to reach a final $\mathrm{pH}$ of ca.3 and then pepsin $(3 \mathrm{mg} / \mathrm{mL})$ was added. After washing bacterial pellets twice, they were suspended in $\mathrm{RSM}$ and incubated at $37^{\circ} \mathrm{C}$ for $3 \mathrm{hrs}^{13}$. For each test, bacterial viable count was done, and the resistant strains were defined as those whose initial counts did not decrease by more than one $\log$ after the indicated incubation period $^{14}$.

\section{Cell surface hydrophobicity}

Bacterial cultures were harvested by centrifugation followed by pellet resuspension in PBS pH 7 to an $\mathrm{OD}_{630}$ of approximately 0.6. An aliquot of $1 \mathrm{~mL}$ of xylene was added to test tubes containing $3 \mathrm{~mL}$ of washed cells. Tubes were vortexed for 2 mins and the suspensions were left for 30 mins before measuring the $\mathrm{OD}_{630}$ of the aqueous phase. Hydrophobicity was calculated as follows:

$$
\begin{gathered}
\text { Hydrophobicity } \%=\left[\left(\text { initial } \mathrm{OD}_{630}-\mathrm{OD}_{630}\right.\right. \\
\text { with xylene } \left.) /\left(\text { initial } \mathrm{OD}_{630}\right)\right] \times 100 .
\end{gathered}
$$

The strains were classified as: those with low hydrophobicity (0-35\%), moderate hydrophobicity (36-70\%), and high hydrophobicity $(71-100 \%)^{15}$. Data were expressed as means \pm S.D.

\section{Auto-aggregation}

Bacterial cultures, in MRS broth, were centrifuged and the pellets were resuspended in PBS pH 7 to approximately $10^{8} \mathrm{CFU} / \mathrm{mL}$. Each suspension was vortexed for $10 \mathrm{~s}$ and incubated for $5 \mathrm{hrs}$ at room temperature. A volume of 200 $\mu \mathrm{L}$ of the upper part of each suspension was withdrawn at 0 and $5 \mathrm{hrs}$ intervals to measure the absorbance at $630 \mathrm{~nm}$. The percentage of auto-aggregation was calculated as follows:

$$
\text { Auto-aggregation }(\%)=1-\left(\mathrm{A}_{\mathrm{t}} / \mathrm{A}_{0}\right) \times 100
$$

Where $\mathrm{A}_{0}$ and $\mathrm{A}_{\mathrm{t}}$ are the absorbance values at $\mathrm{t}$ $=0 \mathrm{hrs}$ and $5 \mathrm{hrs}$, respectively ${ }^{16}$. Data were expressed as means \pm S.D.

\section{Antimicrobial activity of LAB isolates using the agar overlay technique}

The antimicrobial activity of LAB isolates was determined against the standard strains: Staphylococcus aureus ATCC 6538, Escherichia coli NCTC 10418, Listeria monocytogenes EGD-e (serotype 1/2a), Salmonella enterica subsp. enterica serovar Typhimurium ATCC 14028 and Candida albicans ATCC 231. Two $\mu \mathrm{L}$ of overnight culture of each LAB strain were spotted on MRS agar plates and incubated aerobically at $37^{\circ} \mathrm{C}$ for $24-48 \mathrm{hrs}$. The plates were then overlaid with $10 \mathrm{~mL}$ of soft $(0.6 \% \mathrm{w} / \mathrm{v}$ agar $)$ Müller-Hinton medium, or Sabouraud Dextrose medium (for C. albicans) seeded with $1 \% \mathrm{v} / \mathrm{v}$ of an overnight culture of the tested pathogen (final count of $10^{6} \mathrm{CFU} / \mathrm{mL}$ ). After $24-48 \mathrm{hrs}$, inhibition zones around the LAB spots were measured. Strains showing inhibition zone diameters of more than $20 \mathrm{~mm}, 10$ to $20 \mathrm{~mm}$, and less than $10 \mathrm{~mm}$ were considered as strong, intermediate, and low inhibitors of microbial growth, respectively ${ }^{2}$.

\section{Phenotypic characterization of some virulence factors among selected probiotic candidates}

To test for gelatinase activity, overnight cultures of the tested isolates were spot inoculated on gelatin agar plates and incubated for $48 \mathrm{hrs}$, then, flooded with $10 \mathrm{~mL}$ saturated ammonium sulfate. The presence of a clear zone around the colonies showed gelatinase enzyme production ${ }^{17}$. For the detection of DNase activity, the overnight cultures of isolates were spot inoculated on DNase agar 
plates and incubated for $48 \mathrm{hrs}$. The cultures were flooded with $10 \mathrm{~mL} 1 \mathrm{~N} \mathrm{HCl}$. The appearance of clear zones around the colonies confirmed DNase production ${ }^{17}$. Isolates were also tested for hemolytic activity by streaking on blood agar plates. After incubation for 48 hrs, the plates were examined for $\alpha$-, $\beta$ - or $\gamma$ hemolysis $^{12}$. In all virulence tests, Staphylococcus aureus ATCC 6538 was used as a positive control.

Determination of the minimum inhibitory concentrations (MICs) of some antibiotics against selected probiotic candidates using the broth microdilution technique

Overnight cultures of selected LAB isolates were centrifuged at $7000 \mathrm{rpm}$ for 10 mins. Cell pellets were adjusted to $\mathrm{OD}_{600}$ of $0.2-0.3$, then diluted 100-fold in double strength MRS broth. A volume of $100 \mu \mathrm{L}$ of diluted LAB inoculum was added to $100 \mu \mathrm{L}$ of two-fold serial dilutions of selected antibiotics in a sterile 96-well microtiter plate to reach a final count of $5 \times 10^{5} \mathrm{CFU} / \mathrm{mL}$. Negative and positive controls were included in the test.
After aerobic incubation at $37^{\circ} \mathrm{C}$ for $48 \mathrm{hrs}$, results were recorded using microtiter plate reader at $\mathrm{OD}_{630} \mathrm{~nm}$ (Biotek ELx800, USA) ${ }^{12 \& 18}$. Results were interpreted according to the EFSA guidelines (2018) ${ }^{19}$.

\section{Detection of genes conferring antibiotic resistance}

DNA extraction from the tested LAB isolates was done as previously described ${ }^{20}$. PCR was employed to detect seven antibiotic resistance genes: ermB, aac (6')-aph( (2"), aph(3")-III, bla, blaZ, vanX, and gyr $\mathrm{A}^{21-23}$. All primers used are listed in table 1. The PCR products were separated by electrophoresis (Hoefer Scientific, USA) on a $1 \%$ agarose gel containing $0.2 \mu \mathrm{g} / \mathrm{mL}$ ethidium bromide for 25 mins in $1 \mathrm{X}$ TBE buffer. The sizes of the PCR products were determined by comparison with a molecular-sized standard (100 bp DNA ladder, Thermo Fisher Scientific, UK). The bands were visualized under UV light using a gel documentation system (High-Performance UV transilluminator, UVP, USA).

Table 1: Primers used for the amplification of 16s rRNA and genes encoding for resistance to different antibiotics among selected potential probiotic candidates.

\begin{tabular}{|c|c|c|c|}
\hline Target gene & Nucleotide sequence $\left(5^{\prime} \rightarrow 3^{\prime}\right)$ & $\begin{array}{l}\text { Amplicon } \\
\text { size }\end{array}$ & Reference \\
\hline 16s rRNA & $\begin{array}{l}\text { F: (5'- AGAGTTTGATCMTGGCTCAG -3') } \\
\text { R: (5'- TACGGYTACCTTGTTACGACTT -3') }\end{array}$ & 1530 bp. & 10 \\
\hline erm $\mathrm{B}$ & $\begin{array}{l}\text { F: (5'- CATTTAACGACGAAACTGGC -3') } \\
\text { R: (5'GGAACATCTGTGGTATGGCG -3') }\end{array}$ & 425 bp. & 21 \\
\hline $\begin{array}{l}\operatorname{aac}\left(6^{\prime}\right)- \\
\operatorname{aph}\left(2^{\prime \prime}\right)\end{array}$ & $\begin{array}{l}\text { F: (5'- CCAAGAGCAATAAGGGCATA -3') } \\
\text { R: (5'- CACTATCATAACCACTACCG -3')' }\end{array}$ & $220 \mathrm{bp}$. & 21 \\
\hline $\operatorname{aph}(3, ')-I I I$ & $\begin{array}{l}\text { F: (5'- GCCGATGTGGATTGCGAAAA -3') } \\
\text { R: (5'- GCTTGATCCCCAGTAAGTCA -3') }\end{array}$ & 292 bp & 21 \\
\hline bla & $\begin{array}{l}\text { F: (5'- CATARTTCCGATAATASMGCC -3') } \\
\text { R: (5'- CGTSTTTAACTAAGTATSGY -3') }\end{array}$ & 297 bp. & 22 \\
\hline blaZ & $\begin{array}{l}\text { F: (5'- ACTTCAACACCTGCTGCTTTC -3') } \\
\text { R: (5'- TAGGTTCAGATTGGCCCTTAG -3') }\end{array}$ & 240 bp. & 23 \\
\hline $\operatorname{van} \mathrm{X}$ & $\begin{array}{l}\text { F: (5'- TCGCGGTAGTCCCACCATTCGTT -3') } \\
\text { R: (5'- AAATCATCGTTGACCTGCGTTAT -3') }\end{array}$ & 454 bp. & 22 \\
\hline gyrA & $\begin{array}{l}\text { F: (5'- CAMCGKCGKATTCTTTACGGAATG-3') } \\
\text { R: (5'- TTRTTGATATCRCGBAGCATTTC-3') }\end{array}$ & 286 bp & 22 \\
\hline
\end{tabular}


Assessment of the mechanism of antimicrobial activity of potential probiotic candidates against different standard strains

The mechanism of the antimicrobial activity of selected LAB isolates was determined against the previously mentioned standard strains. The overnight culture of each LAB isolate was centrifuged, and the supernatant was filtered using a syringe filter $(0.2-\mu \mathrm{m} \text { pore size })^{24}$. The prepared CFS was further neutralized (nCFS) to $\mathrm{pH} 6.5$ using $5 \mathrm{M}$ $\mathrm{NaOH}$. In sterile 96-well microtiter plate, 100 $\mu \mathrm{L}$ of CFS before and after neutralization were added to $100 \mu \mathrm{L}$ of bacterial suspension inoculated in double strength Luria-Bertani broth (or Sabouraud Dextrose broth in case of C. albicans) to obtain a final inoculum of approximately $10^{6} \mathrm{CFU}$ per well. Positive and negative controls were included in the experiment. The plates were incubated at $37^{\circ} \mathrm{C}$ for $24 \mathrm{hrs}$, and the $\mathrm{OD}_{630}$ was measured. The total percent inhibition of bacterial growth was calculated as follows:

$\%$ inhibition $=[(\mathrm{OD}$ of positive control $-\mathrm{OD}$ of sample)/OD of positive control] x 100

Data were expressed as means \pm S.D. ${ }^{25}$.

Evaluation of the antibacterial activity of $L$. plantarum in combination with other antibiotics against pathogenic clinical isolates using time-kill assay

The antibacterial activity of $L$. plantarum, isolated from fermented grapes, was assessed in combination with gentamicin or ceftazidime, against uropathogenic S. aureus or E. coli isolates. First, the MIC values of the antibiotics or the CFS of L. plantarum against the selected isolates were determined using the broth microdilution technique. Then, $5 \mathrm{~mL}$ of double strength nutrient broth containing $1 / 4 \mathrm{MIC}$ of the tested antibiotic with $1 / 4$ MIC of the CFS of L. plantarum were added to $5 \mathrm{~mL}$ of overnight culture of either $S$. aureus or $E$. coli so that its final count was approximately $10^{6} \mathrm{CFU} / \mathrm{mL}$. Samples were kept in shaking incubator at 150 $\mathrm{rpm}, 37^{\circ} \mathrm{C}$ and a volume of $100 \mu \mathrm{L}$ was aseptically withdrawn at $0,3,6$ and $24 \mathrm{hrs}$, tenfold serially diluted then dropped onto nutrient agar plates. Average number of colonies/sectors was counted after $24 \mathrm{hrs}$ incubation period and the log number of survivors per $\mathrm{mL}$ of each clinical isolate, before and after treatment, was plotted against killing time. The inhibitory effect of the antibiotic or CFS of L. plantarum on $S$. aureus or E. coli isolates, at the same used concentrations, were also tested and plotted. The results were interpreted as previously described by Chambers and Sande ${ }^{26}$.

Assessment of the anti-biofilm activity of the nCFS of different probiotic candidates on $S$. aureus biofilm formation

CFS of each of the tested probiotics was prepared as discussed earlier using Tween 80free MRS broth then it was neutralized by $5 \mathrm{M}$ $\mathrm{NAOH}$ to $\mathrm{pH} 6.5^{24}$. The tested $S$. aureus clinical isolate was cultured in sterile Tryptone soya broth supplemented with $0.5 \%$ (w/v) glucose. Then, $100 \mu \mathrm{L}$ of the diluted culture were added to 96-well microtiter plate containing $100 \mu \mathrm{L}$ of $\mathrm{nCFS}$ of the probiotic so that the final count of $S$. aureus was ca. $10^{6}$ $\mathrm{CFU} / \mathrm{mL}$. After incubation for $24 \mathrm{hrs}$ at $37^{\circ} \mathrm{C}$, the medium was discarded, and planktonic cells were removed by gentle washing with sterile PBS. The biofilms were fixed with $200 \mu \mathrm{L}$ methanol for 15 mins, stained with $200 \mu \mathrm{L}$ of $1 \%$ crystal violet for 20 mins, and rinsed thrice with water. After dissolving crystal violet with $200 \mu \mathrm{L}$ of $33 \%$ acetic acid, absorbance at 630 $\mathrm{nm}$ was measured and the percentage inhibition of biofilm formation was calculated as:
Percentage inhibition $=100-[(\mathrm{OD}$ of wells in the presence of CFS X 100) / OD of control wells].

Data were expressed as means \pm S.D. ${ }^{27}$.

\section{RESULTS AND DISCUSSION}

\section{Results}

\section{Collection and isolation of microorganisms} from natural sources

Different LAB strains were collected from various natural sources and the results are illustrated in table 2 . The table showed that, out of 47 samples collected, nineteen LAB isolates were obtained; 7 from dairy products (D1-D7), 6 from fermented beverages (F1-F6), 3 from breast milk (B1-B3) while only one isolate was obtained from either a vaginal swab, infant stool or fermented grapes, and were given the codes V1, S1 and G1, respectively. All these isolates were confirmed to be acid producing bacteria as manifested by the presence of clear zones around the colonies in $\mathrm{CaCO}_{3}$ test. 
Table 2: Identification and morphology of different lactic acid bacteria obtained from natural origins and their designated codes.

\begin{tabular}{|c|c|c|c|}
\hline Isolate source & Designated code & Morphology & Identification $^{\mathrm{a}}$ \\
\hline \multirow{3}{*}{ Breast milk } & $\mathrm{B} 1$ & Cocci & Pediococcus acidilactici \\
\hline & $\mathrm{B} 2$ & Cocci & Enterococcus faecalis \\
\hline & B3 & Rods & Limosilactobacillus fermentum \\
\hline Vaginal swab & $\mathrm{V} 1$ & Rods & Ligilactobacillus salivarius \\
\hline Infant stool & S1 & Cocci & Enterococcus avium \\
\hline \multirow{7}{*}{ Dairy products } & D1 & Rods & Lactobacillus delbrueckii \\
\hline & $\mathrm{D} 2$ & Cocci & Lactococcus lactis \\
\hline & D3 & Cocci & Enterococcus faecalis \\
\hline & D4 & Cocci & Lactococcus garvieae \\
\hline & D5 & Cocci & Lactococcus lactis \\
\hline & D6 & Cocci & Enterococcus faecalis \\
\hline & D7 & Cocci & Lactococcus lactis \\
\hline \multirow{6}{*}{$\begin{array}{l}\text { Fermented } \\
\text { beverages }\end{array}$} & F1 & Cocci & Leuconostoc holzapfelii \\
\hline & $\mathrm{F} 2$ & Rods & Lacticaseibacillus paracasei \\
\hline & F3 & Rods & Lactobacillus hilgardii \\
\hline & $\mathrm{F} 4$ & Coccoid & Weissella confuse \\
\hline & F5 & Coccoid & Weissella cibaria \\
\hline & F6 & Cocci & Leuconostoc mesenteroides \\
\hline Fermented grapes & G1 & Rods & Lactiplantibacillus plantarum \\
\hline
\end{tabular}

${ }^{a}$ L. fermentum, L. salivarius, L. paracasei, and L. plantarum changed into Limosilactobacillus fermentum, Ligilactobacillus salivarius, Lacticaseibacillus paracasei, Lactiplantibacillus plantarum, respectively ${ }^{28}$.

\section{Characterization and identification of LAB isolates}

According to biochemical and 16s rRNA sequencing results, the collected LAB isolates' codes, sources, morphology, and identification are summarized in table 2 .

Six isolates $(31.6 \%)$ belonged to the Lactobacillus spp.; F2: Lacticaseibacillus paracasei (formerly known as Lactobacillus paracasei), F3: Lactobacillus hilgardii, B3: Limosilactobacillus fermentum (formerly known as Lactobacillus fermentum), V1: Ligilactobacillus salivarius (formerly known as Lactobacillus salivarius), D1: Lactobacillus delbrueckii and G1: Lactiplantibacillus plantarum (formerly known as Lactobacillus plantarum $)^{28}$. Four isolates were identified as Enterococcus spp.: 3 Enterococcus faecalis isolates B2, D3 and D6 and a single Enterococcus avium isolate S1. The obtained Lactococcus spp. (4 isolates) were isolated from dairy products; 3 Lactococcus lactis isolates: D2, D5 and D7 and one Lactococcus garvieae isolate: D4. From fermented beverages, two isolates belonged to
Leuconostoc spp. were obtained, (F1: Leuconostoc holzapfelii and F6: Leuconostoc mesenteroides) and two other isolates were identified as Weissella spp.; F4: Weissella confusa and F5: Weissella cibaria. Only one isolate from breast milk, B1, was identified as Pediococcus acidilactici.

\section{Survival of LAB isolates under conditions simulating human GIT}

Most of the tested isolates showed less than one $\log$ reduction in number of survivors when present in a saline media of $\mathrm{pH} 3$. However, addition of pepsin to such media caused no change in bacterial count among the majority of the bacteria tested as shown in table 3. None of the tested LAB isolates were able to tolerate pepsin or even to grow at $\mathrm{pH} 2$, but upon addition of RSM, 7 isolates showed acceptable tolerance $(<1 \log$ reduction). These isolates were B1, V1, F3, D1, D3, D6 and G1. Upon exposing the isolates to $0.3 \%$ ox-bile at $\mathrm{pH} 8$ for 4 hrs, most of isolates (73.7\%) showed more than one log reduction in survivors. On the contrary, they had a good tolerance to pancreatin (Table 3). 
Table 3: Number of survivors in colony forming units of different lactic acid bacteria strains under different stress conditions in the GIT.

\begin{tabular}{|c|c|c|c|c|c|c|c|c|c|c|c|c|}
\hline \multirow{3}{*}{ Code } & \multicolumn{12}{|c|}{ Viable cell count (Log CFU/mL) } \\
\hline & \multicolumn{2}{|c|}{$\mathrm{pH} 3$} & \multicolumn{2}{|c|}{ pH3 + pepsin } & \multicolumn{2}{|c|}{$\mathrm{pH} 2+$ pepsin } & \multicolumn{2}{|c|}{ RSM $^{\mathrm{b}}$} & \multicolumn{2}{|c|}{ Bile } & \multicolumn{2}{|c|}{ Pancreatin } \\
\hline & $0 \mathrm{hrs}$ & $3 \mathrm{hrs}$ & $0 \mathrm{hrs}$ & $3 \mathrm{hrs}$ & $0 \mathrm{hrs}$ & $3 \mathrm{hrs}$ & $0 \mathrm{hrs}$ & $3 \mathrm{hrs}$ & $0 \mathrm{hrs}$ & $4 \mathrm{hrs}$ & $0 \mathrm{hrs}$ & $4 \mathrm{hrs}$ \\
\hline B1 & 10.34 & 9.74 & 10.11 & 10.11 & 9.83 & 0 & 10.19 & 9.54 & 9.97 & 9.8 & 9.7 & 9.7 \\
\hline B2 & 9.43 & 9.43 & 9.3 & 9.3 & 9.23 & 7 & 9.51 & 6.18 & 9.32 & 6.51 & 9.6 & 9.6 \\
\hline B3 & 9.8 & 9.18 & 9.52 & 8.82 & 9.78 & 7 & 9.85 & 8.76 & 8.94 & 3.3 & 10 & 10 \\
\hline V1 & 9.56 & 9.48 & 9.38 & 9.38 & 9.74 & 0 & 9.88 & 9.47 & 9.72 & 6.22 & 9.6 & 9.6 \\
\hline S1 & 9.49 & 8.78 & 9.4 & 9.4 & 9.28 & 0 & 9.38 & 7.89 & 8.98 & 5.72 & 9.51 & 9.51 \\
\hline D1 & 9.17 & 8.67 & 9.17 & 9.17 & 9.26 & 0 & 9.24 & 9.24 & 9.02 & 8.63 & 9.47 & 9.47 \\
\hline D2 & 9.04 & 8.7 & 9.22 & 9.13 & 9.01 & 0 & 9.41 & 4.86 & 9.14 & 5.72 & 9.48 & 9.32 \\
\hline D3 & 8.8 & 7.41 & 9.28 & 9.2 & 9.24 & 0 & 8.89 & 8.44 & 8.68 & 3.7 & 9.08 & 8.93 \\
\hline D4 & 7.76 & 7.32 & 8.42 & 8.42 & 8.24 & 0 & 8.29 & 6.54 & 8.32 & 6.95 & 8.6 & 7.9 \\
\hline D5 & 9.6 & 8.8 & 9.65 & 9.65 & 9.58 & 4 & 9.45 & 8.15 & 9.16 & 7.57 & 9.74 & 9.74 \\
\hline D6 & 9.08 & 9.08 & 9.43 & 9.43 & 9.43 & 5 & 9.5 & 9.18 & 9.33 & 7.48 & 9.44 & 9.44 \\
\hline D7 & 9.3 & 7.75 & 9.65 & 9.54 & 9.47 & 0 & 9.78 & 6.26 & 8.11 & 6.65 & 9.3 & 9.3 \\
\hline $\mathrm{F} 1$ & 9.18 & 7.46 & 9.02 & 9.02 & 9.34 & 4 & $8.94^{\circ}$ & 6.4 & 8.51 & 6.01 & 8.65 & 8.34 \\
\hline $\mathrm{F} 2$ & 9.45 & 9.45 & 9.5 & 9.5 & 9.65 & 7 & 9.88 & 7.51 & 9.81 & 9.3 & 9.7 & 9.7 \\
\hline F3 & 9.57 & 9.57 & 9.48 & 9.33 & 9.37 & 0 & 8.88 & 8.17 & 9.51 & 9.18 & 9.88 & 9.54 \\
\hline F4 & 6.7 & 6.61 & 6.18 & 6.03 & 9.34 & 0 & 8.68 & 7.4 & 9.27 & 3.3 & 7.54 & 7.54 \\
\hline F5 & 9.51 & 9.11 & 8.66 & 7.92 & 9.16 & 0 & 9.57 & 7.36 & 9.44 & 5.25 & 8.02 & 8.02 \\
\hline F6 & 9.52 & 9.52 & 9.6 & 9.6 & 9.37 & 0 & 9.48 & 4.19 & 9.63 & 7.81 & 9.4 & 8.9 \\
\hline G1 & 10.33 & 10.21 & 10.04 & 10.04 & 9.68 & 5 & 10.06 & 10.06 & 10 & 9.37 & 9.88 & 9.88 \\
\hline
\end{tabular}

${ }^{a}$ values are means with standard deviation ranging from 0-0.9.

${ }^{\mathrm{b}}$ Reconstituted Skimmed Milk.

Cell surface hydrophobicity and autoaggregation

Figure 1 clearly demonstrated the wide discrepancies between the bacteria tested either in their cell hydrophobicity characteristics or their autoaggregation capabilities. About $31.6 \%$ of the isolates showed high cell surface hydrophobicity ranging between 93 and $76 \%$. Only one isolate, $W$. confusa F4, showed medium hydrophobicity of $40 \%$. The rest of the isolates possessed low hydrophobicity (Fig. 1). The percentage of auto-aggregation ranged between 78 and $26 \%$. The highest $\%$ of autoaggregation was detected in case of $L$. garvieae: D4 (78\%) while the lowest autoaggregation ability was observed in case of $L$. lactis D7 and E. faecalis B2 which showed only $26 \%$ of auto-aggregation (Fig. 1).

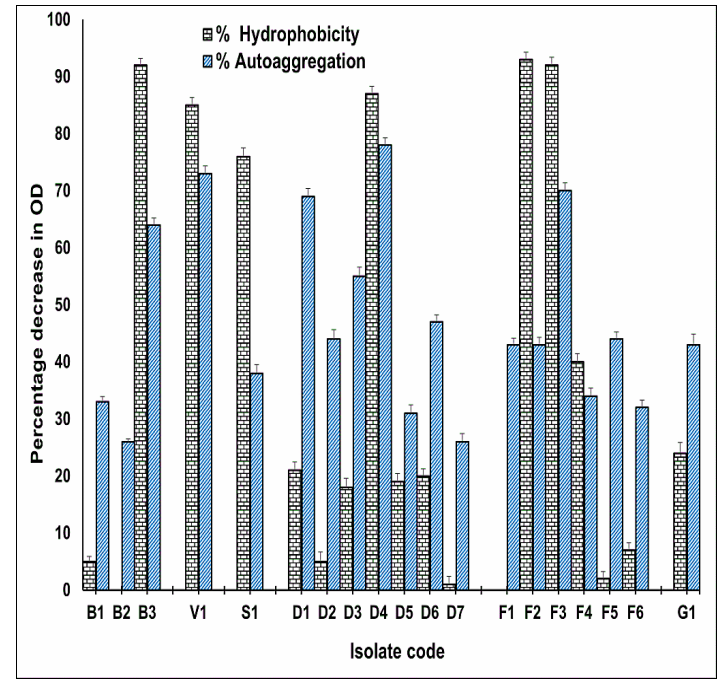

Fig. 1: Percentage of cell surface hydrophobicity and auto-aggregation among the collected $\mathrm{LAB}$ isolates. 


\section{Antimicrobial activity of LAB isolates}

The antimicrobial effect of the probiotics studied using the agar overlay method against common standard strains is illustrated in figure 2. Most of the LAB isolates tested were strong inhibitors of the growth of either $E$. coli $(63.2 \%)$ or $S$. enterica $(84.2 \%)$, while the rest intermediately inhibited their growth. However, their inhibitory effect against $L$. monocytogenes was almost equally divided between strong and intermediate. On the other hand, most of the LAB isolates intermediately inhibited the growth of $S$. aureus except $W$. cibaria F5, that caused strong inhibition. None of the tested LAB isolates showed any inhibition activity against $C$. albicans (Fig. 2).

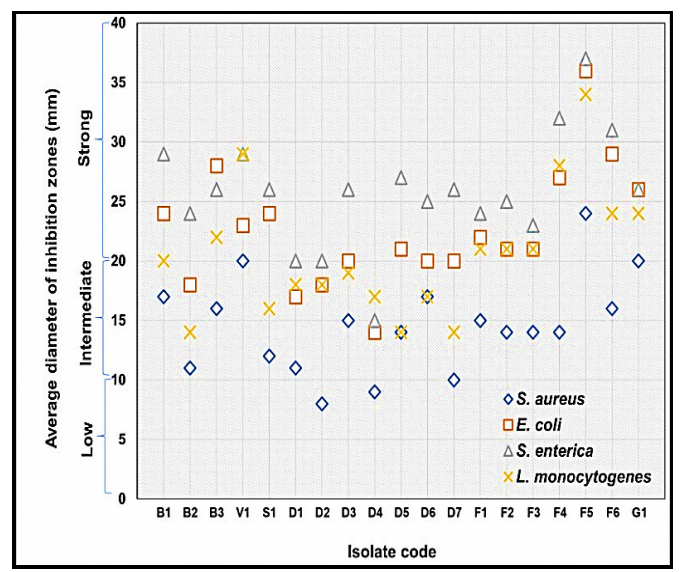

Fig. 2: Antibacterial activity of LAB isolates against selected standard strains using the agar overlay technique.
Based on the previous results, five isolates were considered to be promising probiotic candidates and were included in the rest of the experiments. These isolates were: $P$. acidilactici $\mathrm{B} 1$, L. delbrueckii $\mathrm{D} 1$, L. paracasei $\mathrm{F} 2$, L. hilgardii $\mathrm{F} 3$, and L. plantarum $\mathrm{G} 1$.

\section{Screening for some virulence factors and antibiotic susceptibility of the chosen probiotic candidates}

All tested isolates were non hemolytic and lacked both gelatinase and deoxyribonuclease enzymes. The MICs of each of the tested antibiotics against the LAB isolates are listed in table 4. All the tested strains were resistant to kanamycin, gentamicin, ciprofloxacin, and vancomycin with MIC ranges of (512 - >1024 $\mu \mathrm{g} / \mathrm{mL}),(32->512 \mu \mathrm{g} / \mathrm{mL}),(8->512 \mu \mathrm{g} / \mathrm{mL})$, and $(4->256 \mu \mathrm{g} / \mathrm{mL})$, respectively. Only D1 and F2 showed susceptibility to ampicillin (MIC $=2 \mu \mathrm{g} / \mathrm{mL}$ ). In case of erythromycin, D1 and $\mathrm{F} 3$ were sensitive $(\mathrm{MIC}=0.5$ and $1 \mu \mathrm{g} / \mathrm{mL}$, respectively). Among the seven tested antibiotic resistance genes, 4 genes $\left(a a c\left(6^{\prime}\right)\right.$ $\operatorname{aph}\left(2^{\prime \prime}\right)$, gyr A, erm B and blaZ were detected in all of the tested isolates. aph(3")-III gene was detected in $\mathrm{B} 1, \mathrm{~F} 2$ and $\mathrm{G} 1$ while vanX gene was detected in $\mathrm{B} 1, \mathrm{D} 1, \mathrm{~F} 2$, and $\mathrm{G} 1$. On the contrary, bla gene was not detected in any of the isolates (Table 4).

Table 4: Minimum inhibitory concentration $(\mu \mathrm{g} / \mathrm{mL})$ and genes of resistance to some selected antibiotics among lactic acid bacteria isolates using polymerase chain reaction.

\begin{tabular}{|c|c|c|c|c|c|c|}
\hline \multirow[t]{2}{*}{ Antibiotic } & \multirow{2}{*}{$\begin{array}{l}\text { Genes of } \\
\text { resistance }\end{array}$} & \multicolumn{5}{|c|}{$\begin{array}{c}\text { Isolate name } \\
\mathrm{MIC}(\mu \mathrm{g} / \mathrm{mL}), \text { resistance pattern } \\
\end{array}$} \\
\hline & & P. acidilactici & L. delbrueckii & L. paracasei & L. hilgardii & L. plantarum \\
\hline & & $8, \mathrm{R}$ & $2, \mathrm{~S}$ & $2, \mathrm{~S}$ & $4, \mathrm{R}$ & $4, \mathrm{R}$ \\
\hline Ampicillin & bla & - & - & - & - & - \\
\hline & blaZ & + & + & + & + & + \\
\hline Kanamycin & $\operatorname{aph}\left(3^{\prime \prime \prime}\right)-I I I$ & $\begin{array}{c}>1024, \mathrm{R} \\
+\end{array}$ & $\begin{array}{c}512, \mathrm{R} \\
-\end{array}$ & $\begin{array}{c}1024, \mathrm{R} \\
+\end{array}$ & $>1024, \mathrm{R}$ & $\begin{array}{c}>1024, \mathrm{R} \\
+\end{array}$ \\
\hline Gentamycin & $\operatorname{aac}\left(6^{\prime}\right)-\operatorname{aph}\left(2^{\prime \prime}\right)$ & $\begin{array}{c}512, \mathrm{R} \\
+\end{array}$ & $\begin{array}{c}64, \mathrm{R} \\
+ \\
\end{array}$ & $\begin{array}{c}128, \mathrm{R} \\
+\end{array}$ & $\begin{array}{c}32, \mathrm{R} \\
+ \\
\end{array}$ & $\begin{array}{c}>512, \mathrm{R} \\
+\end{array}$ \\
\hline $\begin{array}{c}\text { Ciprofloxaci } \\
\mathrm{n}\end{array}$ & gyrA & $\begin{array}{c}256, \mathrm{R} \\
+\end{array}$ & $\begin{array}{c}256, \mathrm{R} \\
+\end{array}$ & $\begin{array}{c}8, \mathrm{R} \\
+\end{array}$ & $\begin{array}{c}128, \mathrm{R} \\
+\end{array}$ & $\begin{array}{c}>512, \mathrm{R} \\
+\end{array}$ \\
\hline Vancomycin & $\operatorname{van} \mathrm{X}$ & $\begin{array}{c}>256, \mathrm{R} \\
+\end{array}$ & $\begin{array}{c}4, \mathrm{R} \\
+ \\
\end{array}$ & $\begin{array}{c}>256, \mathrm{R} \\
+\end{array}$ & $\begin{array}{c}>256, \mathrm{R} \\
-\end{array}$ & $\begin{array}{c}>256, \mathrm{R} \\
+\end{array}$ \\
\hline Erythromycin & erm B & $\begin{array}{c}2, \mathrm{R} \\
+ \\
\end{array}$ & $\begin{array}{c}0.5, \mathrm{~S} \\
+ \\
\end{array}$ & $\begin{array}{c}2, \mathrm{R} \\
+ \\
\end{array}$ & $\begin{array}{c}1, S \\
+ \\
\end{array}$ & $\begin{array}{c}2, \mathrm{R} \\
+ \\
\end{array}$ \\
\hline
\end{tabular}

${ }^{\mathrm{a}}$ The MICs are interpreted according to European food safety authority (EFSA) $2018^{19}$. S: sensitive, R: resistant. 
Assessment of the mechanism of the antimicrobial activity of the chosen probiotics against standard strains

To assess the cause of the antibacterial activity of the probiotics tested against the previously mentioned isolates, the inhibitory effect of their CFS was plotted in figure 3 before and after neutralization with $\mathrm{NaOH}$. Generally, the non-neutralized CFS of all the tested probiotics showed more than $90 \%$ growth inhibition against the clinical isolates tested. However, upon neutralization, the antibacterial activity of both D1 and G1 was abolished against $S$. aureus while that of B1, F2, and F3 was decreased by 4.2, 3.7, and 3.8 folds, respectively (Fig. 3).

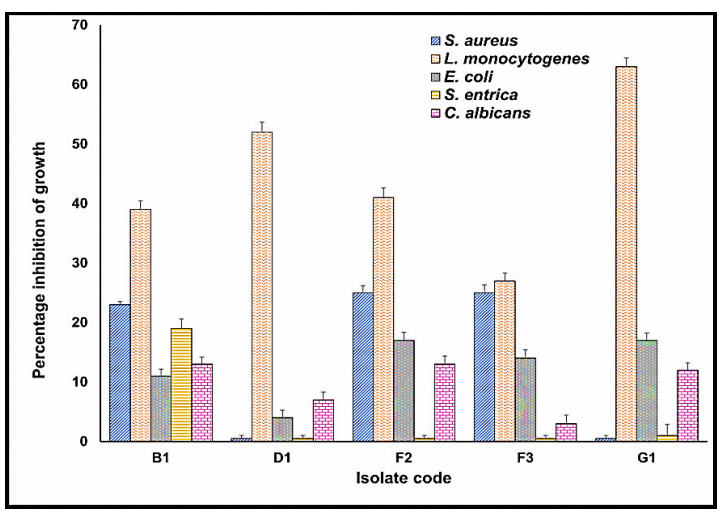

Fig. 3: Comparative antimicrobial activity of neutralized cell-free supernatant of potential probiotics against selected Gram-positive, Gram-negative, and Candida albicans standard strains.

Neutralization of the CFS of D1 resulted in 26.1-fold reduction in growth of E. coli. Such effect was less obvious with the rest of probiotics against the same isolate. The neutralization of the CFS of D1, F2, and F3 completely eliminated the antibacterial activity against $S$. enterica, while nCFS of G1 and B1 led to 70.8 and 4.9 -fold reduction, respectively against salmonella (Fig. 3).
Against L. monocytogenes, percentage inhibition of growth, after neutralization of CFS of probiotics, ranged between $27 \%$ in F3 and $63 \%$ in G1. Similarly, in case of $C$. albicans, the neutralization of the CFS significantly diminished the antifungal activity of the tested probiotics. The percentage of inhibition of growth ranged between 70.8 and 44.3 in case of non-neutralized CFS, while it ranged between 12.9 to 2.9 in case of nCFS (Fig. 3).

\section{Time-kill curve of the CFS of $L$. plantarum} combined with antibiotics

Figures 4A-4D illustrate the effect of CFS of $L$. plantarum $\mathrm{G} 1$ either alone or combined with an antibiotic against either $E$. coli or $S$. aureus clinical isolates causing urinary tract infections. When tested against E. coli clinical isolate, the combination of G1 with ceftazidime showed a synergistic effect after 24 hrs with about $2.43 \mathrm{log}$ reduction in survivors compared to the most active single component (Fig. 4A). Similarly, another synergistic effect was noticed with the combination of G1 with gentamicin, after $24 \mathrm{hrs}$, with $2.06 \mathrm{log}$ reduction in survivors (Fig. 4B). The most promising combination tested against $S$. aureus isolate was that of $\mathrm{G} 1$ with ceftazidime showing a synergistic effect after $24 \mathrm{hrs}$ with $3.63 \mathrm{log}$ reduction in survivors (Fig. 4C). The combination of G1 with gentamicin just resulted in an additive effect after $24 \mathrm{hrs}$ with about 0.47 log reduction in survivors (Fig. 4D).

The anti-biofilm effect of the nCFS of probiotics on uropathogenic $S$. aureus biofilm formation

The effect of the nCFS of the chosen probiotic candidates on the formation of $S$. aureus clinical isolate biofilm was shown in figure 5. About $50 \%$ reduction in biofilm formation resulted upon incubation of nCFS of G1 and F2 with $S$. aureus growing media. A slightly lower percentage of biofilm inhibition was observed in case of B1 and F3 (45 and $43 \%$, respectively). However, the least effect was noticed in case of D1 (only $26 \%$ inhibition of biofilm formation). 

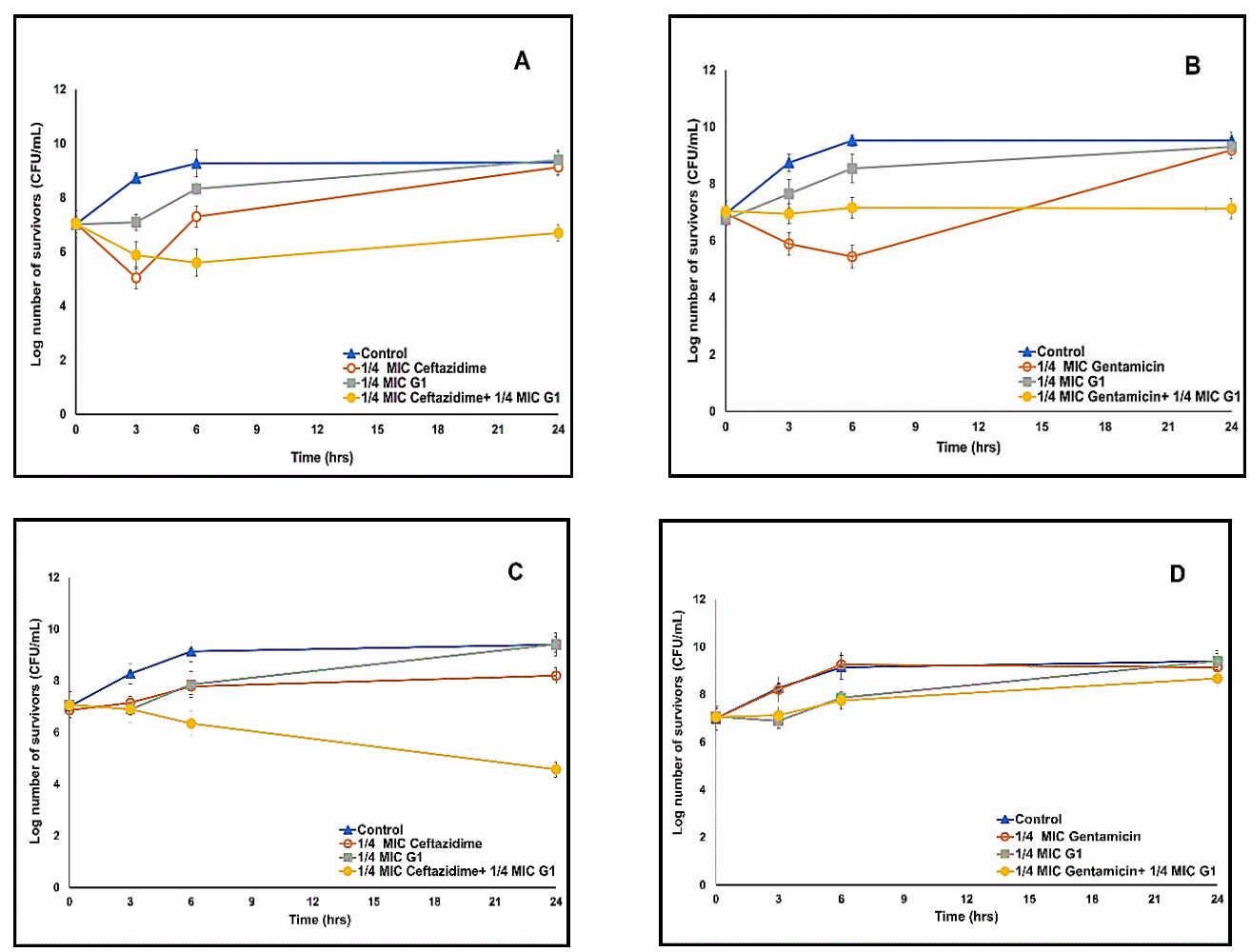

Fig. 4: Time-kill kinetics assay of the cell-free supernatant of L. plantarum against urinary tract pathogens $E$. coli and $S$. aureus combined with different antibiotics. Fig. 4A and 4B represent CFS of L. plantarum combined with ceftazidime and gentamicin, respectively, against E. coli. Fig. 4C and 4D represent CFS of $L$. plantarum combined with ceftazidime and gentamicin, respectively, against $S$. aureus.

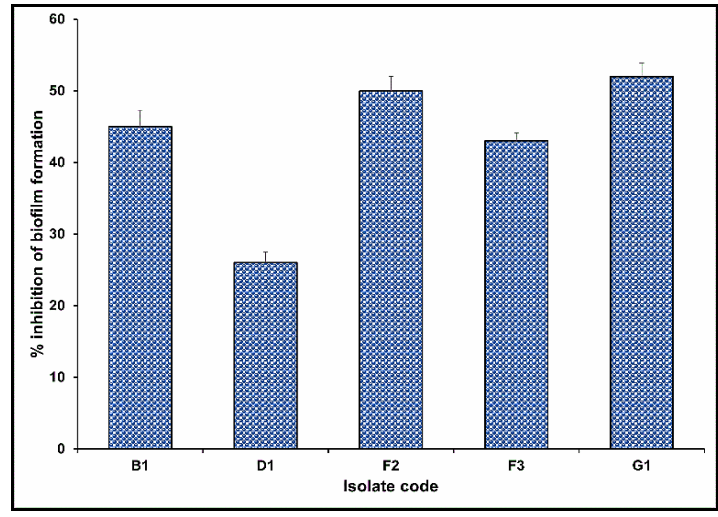

Fig. 5: Effect of the neutralized cell-free supernatant of potential probiotic candidates on biofilm formation of uropathogenic $S$. aureus isolate.

\section{Discussion}

Recently, consumption of probiotics obtained from "unconventional sources" has markedly increased. Current trends are now focusing on getting probiotics from sources different from milk products to be used for lactose intolerant people. Such sources include non-dairy fermented beverages and foods, human breast milk, as well as feces of breastfed infants ${ }^{29}$. In our study, 19 isolates were obtained from various natural sources. Among our isolates, one L. salivarius strain (V1) was isolated from a vaginal swab. In a study conducted by Pino et al., L. salivarius represented $20 \%$ of the lactobacilli isolated from the vagina of healthy women $^{30}$. Some LAB, including Lactobacillus and Leuconostoc genera, are reported to be used as starters for homemade foods and beverages. Also, Weissella spp. have been commonly isolated from various fermented foods $^{31}$. Similarly, our isolates that were isolated from fermented beverages belonged to Leuconostoc spp. (F1 and F6), Lactobacillus spp. (F2 and F3), as well as Weissella spp. (F4 and F5). Bacteria commonly associated with dairy products are related to various genera including Lactobacillus and Lactococcus ${ }^{32}$. In 
addition, the isolation of $E$. faecalis from dairy products has been previously reported ${ }^{33}$. In our study, D1 belonged to Lactobacillus spp., D2, D4, D5 and D7 belonged to Lactococcus spp, while D3 and D6 were identified as E. faecalis.

Probiotic candidates intended to be orally ingested should show resistance to stress conditions encountered in GIT to ensure their beneficial activity ${ }^{34}$. Among the tested isolates, $84.2 \%$ tolerated presence at $\mathrm{pH} 3$ environment and all the isolates tolerated pepsin at $\mathrm{pH} 3$. It is thought that pepsin might help in maintaining the $\mathrm{pH}$ homeostasis of $\mathrm{LAB}$, as well as supporting the role of $\mathrm{H}^{+}$-ATPase in the protection of bacteria ${ }^{35}$. None of the tested isolates tolerated pepsin $(3 \mathrm{mg} / \mathrm{mL})$ at $\mathrm{pH} 2$. However, upon addition of RSM, $36.8 \%$ of the isolates showed acceptable tolerance. This could be attributed to the increase in $\mathrm{pH}$ value due to the addition of RSM or the direct protective effect of the food matrix on the bacterial cells ${ }^{13}$.

In our study, B1, D1, G1, F2 and F3 tolerated $0.3 \%$ ox-bile. The most significant bile resistance mechanisms among Lactobacillus spp. were reported to be due to hydrolysis of bile salt, active efflux of bile salts, as well as modifications in the architecture of cell membrane and cell wall $^{36}$. In addition, tolerance of $P$. acidilactici to bile salt has been previously reported ${ }^{37}$. All the tested isolates tolerated pancreatin. Also, Ruiz-Moyano et al. found that 46 out of 51 tested LAB strains could survive after $3 \mathrm{hrs}$ of exposure to $1.9 \mathrm{mg} / \mathrm{mL}$ of pancreatic enzymes $^{38}$.

LAB strains having hydrophobic cell surface and showing good aggregation capacity could achieve better adherence to the intestinal cells to exert their beneficial effects ${ }^{39}$. Among the tested LAB isolates in this study, the highest hydrophobicity was detected in case of L. paracasei F2 (93\%). However, this value was more than 3 times greater than what was reported by $\mathrm{Xu}$ et al. $^{40}$. The wide variation of auto-aggregation ability among our tested isolates could be explained according to Krausova et al. who illustrated that autoaggregation assays done among probiotic bacteria revealed strain-specific variations irrespective of their taxonomic group or origin $^{41}$. LAB isolates under study showed inhibitory activity against both Gram-negative and Gram-positive bacteria. Such inhibition is commonly associated with the production of various antimicrobial substances, including bacteriocins, organic acids, ethanol, hydrogen peroxide, and acetaldehyde by the probiotic isolates $^{42}$. Pino et al. reported that $L$. salivarius probiotic strain isolated from healthy women vagina showed inhibitory activity against $E$. coli, $S$. aureus and $L$. monocytogenes $^{30}$. In addition, Birri et al. found that E. avium, from infant feces, showed noticeable inhibition of $L$. monocytogenes due to the production of a bacteriocin termed avicin $\mathrm{A}^{43}$. In Egypt, Bassyouni et al. showed that LAB isolates obtained from Egyptian dairy product exerted a promising antibacterial effect against E. coli and Salmonella typhimurium ${ }^{44}$. Also, Tadesse et al. showed that Lactobacillus and Leuconostoc isolates, from traditional Ethiopian fermented beverages, showed antibacterial activity against $S$. aureus, Salmonella spp. and E. coli $\mathrm{O} 157: \mathrm{H}^{45}$. All the tested isolates were non-hemolytic. None of them showed DNase or gelatinase activities. Similarly, Abouloifa et al. had previously reported that the Lactobacillus strains isolated from traditional fermented Moroccan green olives lacked important virulence determinants and that assured the safety of their intake ${ }^{17}$.

On the other hand, all the tested strains were resistant to kanamycin, gentamicin, ciprofloxacin, and vancomycin. Generally, resistance of lactobacilli to aminoglycosides is often high $^{46}$. Also, it is well known that most nucleic acid synthesis inhibitors show low inhibition against the majority of Lactobacillus spp. ${ }^{46}$. Hummel et al. had previously reported that the resistance to aminoglycoside (including gentamicin) and ciprofloxacin among the tested LAB strains was greater than $70 \%{ }^{47}$. Commonly, lactobacilli have been reported to show susceptibility to penicillin ${ }^{46}$. However, among our isolates, only 2 isolates were sensitive to ampicillin. Ali et al. found that L. plantarum and $L$. paracasei strains, isolated from fermented dairy products, showed resistance to vancomycin and ciprofloxacin, but contradictory to our findings, they reported the susceptibility of these strains to gentamicin and erythromycin $^{48}$.

Among the seven tested antibiotic resistance genes, 4 genes $\left(\operatorname{aac}\left(6^{\prime}\right)-\operatorname{aph}\left(2^{\prime \prime}\right)\right.$, 
gyr A, erm B and blaZ) were detected in all of the tested isolates. $\operatorname{aph}\left(3^{\prime \prime}\right)-I I I$ gene was detected in $\mathrm{B} 1, \mathrm{~F} 2$ and $\mathrm{G} 1$ while $\operatorname{vanX}$ gene was detected in B1, D1, F2 and G1. Lactobacilli are commonly recognized to be intrinsically resistant to the glycopeptide vancomycin where this resistance is attributed to the vanX gene encoding the enzyme D-alaD-ala dipeptidase ${ }^{49}$. Moreover, erythromycin resistance genes have been found in various Lactobacillus spp. where the erm $\mathrm{B}$ gene, encoding a rRNA methylase that acts on the $23 \mathrm{~S}$ ribosomal subunit, is the most commonly detected $^{46}$. $\operatorname{aac}\left(6^{\prime}\right)-\operatorname{aph}\left(2^{\prime \prime}\right), \operatorname{aph}\left(3^{\prime}\right)-$ III $a$ and blaZ have been reported to exist much less frequently among lactobacilli ${ }^{46}$. However, among our tested Lactobacillus isolates, each of $a a c\left(6^{\prime}\right)-a p h\left(2^{\prime \prime}\right)$ and blaZ were detected among all the isolates, while $\operatorname{aph}\left(3^{\prime}\right)$-IIIa was detected in F2 and G1.

A great concern has been raised regarding the possible transfer of antibiotic resistance genes from potential probiotic candidates of LAB to other pathogenic bacteria that might exist in GIT $^{50}$. However, possessing intrinsic antibiotic resistance genes in LAB with low horizontal transfer potential to other organisms was considered acceptable for probiotic selection $^{51}$. In addition, Guo et al. reported the failure of the transfer of gyrA from Lactobacillus isolates ${ }^{49}$. The lack of transferability of antimicrobial resistance genes from LAB to pathogenic bacteria has been previously reported. Besides, the threat of lactobacillemia associated with the probiotic Lactobacillus was regarded to be "unequivocally negligible"17. To ensure the safety of the used probiotics, CFS of each of the promising probiotic candidates in our study was prepared and utilized for the rest of the experiments.

To elucidate the mechanism of the antibacterial and antifungal activities of probiotics, CFS of the selected probiotics were compared before and after neutralization against the tested standard strains. The inhibitory activity of the non-neutralized CFS was markedly greater than that of the neutralized ones. Similarly, it has been reported that the neutralization of CFS of Lactobacillus strains with alkali had diminished their antibacterial activity. This finding suggested that the main inhibitory mechanisms might be due to the produced organic acids from glucose fermentation ${ }^{52}$.

To the best of our knowledge, the kinetics of in-vitro combinations of CFS of $L$. plantarum with gentamicin or ceftazidime against $S$. aureus and $E$. coli, using the timekill assay, have not been widely tested. Our results showed that the combinations of G1 with each of ceftazidime and gentamicin showed a synergistic effect against $E$. coli while synergism was only obtained in case of G1/ceftazidime combination against $S$. aureus. The chief bacterial inhibitory essentials produced by lactobacilli include the organic acids and bacteriocins ${ }^{53}$. In their study, Chen et $a l$. showed that the antibacterial activity of Lactobacillus strains was mainly dependent on the production of organic acids that act as permeabilizers of the outer membrane of Gramnegative pathogens thus enhancing the activity of antimicrobial metabolites ${ }^{54}$. In addition, bacteriocin/antimicrobial combinations might have prodigious value in the reduction of the possibility of the development of resistance and reducing the required antibiotic concentration for fruitful treatments ${ }^{55}$.

The nCFS of all the tested probiotic candidates showed inhibition of $S$. aureus biofilm formation with a percentage of inhibition ranging between 26 and 52 . Similarly, Barzegari et al. stated that biosurfactants of both $L$. plantarum and $P$. acidilactici have been reported to inhibit the biofilm formation of $S$. aureus chiefly through affecting the expression of various biofilmrelated genes, as well as hindering the release of the signaling molecules in quorum sensing systems $^{56}$.

In conclusion, the current study showed that breast milk, dairy products, fermented beverages, and fermented grapes were good sources of promising probiotic candidates belonging to both Pediococcus and Lactobacillus spp. In addition, the obtained results highlighted the significance of $L$. hilgardii, as a potential probiotic candidate, although it was not thoroughly investigated in previous studies. This study suggested the utilization of such probiotic candidates to formulate novel probiotics that might act as biotherapeutic agents preventing bacterial infection and biofilm formation. However, invivo trials are crucial to ensure the safety and 
efficacy of these probiotics for human health benefit.

\section{Author disclosure statemnt}

No conflict of interest exists with this publication. All authors have contributed substantially to the manuscript and have approved the final submission.

\section{REFERENCES}

1. M. Kechagia, D. Basoulis, S Konstantopoulou, D. Dimitriadi, K. Gyftopoulou, N. Skarmoutsou, et al., "Health benefits of probiotics: A review", ISRN Nutrition, 2013, 481651 (2013).

2. P. Shokryazdan, C. C. Sieo, R. Kalavathy, J. B. Liang, N. B. Alitheen, M. Faseleh Jahromi, et al., "Probiotic potential of Lactobacillus strains with antimicrobial activity against some human pathogenic strains", Biomed. Res. Int., 2014, 927268 (2014).

3. Y. Nami, N. Abdullah, B. Haghshenas, D. Radiah, R. Rosli and A. Y. Khosroushahi, "Probiotic assessment of Enterococcus durans 6HL and Lactococcus lactis 2HL isolated from vaginal microflora", J. Med. Microbiol., 63, 1044-1051 (2014).

4. L. Fontana, M. Bermudez-Brito, J. PlazaDiaz, S. Munoz-Quezada and A. Gil, "Sources, isolation, characterisation and evaluation of probiotics", Br. J. Nutr., 109, S35-50 (2013).

5. S. Cribby, M. Taylor and G. Reid, "Vaginal microbiota and the use of probiotics", Interdiscip. Perspect. Infect. Dis., 2008, 1-9 (2008).

6. P. Sornsenee, K. Singkhamanan, S. Sangkhathat, P. Saengsuwan and C. Romyasamit, "Probiotic Properties of Lactobacillus Species Isolated from Fermented Palm Sap in Thailand", Probiotics and Antimicrobial Proteins, (2021).

7. A. M. Hammad and T. Shimamoto, "Towards a compatible probioticantibiotic combination therapy: Assessment of antimicrobial resistance in the Japanese probiotics", J. Appl. Microbiol., 109, 1349-1360 (2010).

8. Y. S. Chen, H. C. Wu and F. Yanagida, "Isolation and characteristics of lactic acid bacteria isolated from ripe mulberries in Taiwan", Braz. J. Microbiol., 41, 916-921 (2010).

9. A. Kumar and D. Kumar, "Isolation and characterization of bacteria from dairy samples of Solan in Himachal Pradesh for identification of Lactobacillus spp.", International Journal of Pharmaceutical Sciences Review and Research, 25, 110114 (2014).

10. K. W. Lee, J. M. Shim, S. Park, H. Heo, H. Kim, K. Ham, et al., "Isolation of lactic acid bacteria with probiotic potentials from kimchi, traditional Korean fermented vegetable", LWT - Food Science and Technology, 71, 130-137 (2016).

11. P. A. Maragkoudakis, G. Zoumpopoulou, C. Miaris, G. Kalantzopoulos, B. Pot and E. Tsakalidou, "Probiotic potential of Lactobacillus strains isolated from dairy products", International Dairy Journal, 16, 189-199 (2006).

12. A. A. Argyri, G. Zoumpopoulou, K. G. Karatzas, E. Tsakalidou, G. E. Nychas, E. Z. Panagou, et al., "Selection of potential probiotic lactic acid bacteria from fermented olives by in-vitro tests", Food Microbiology, 33, 282-291 (2013).

13. M. De Angelis, S. Siragusa, M. Berloco, L. Caputo, L. Settanni, G. Alfonsi, et al., "Selection of potential probiotic lactobacilli from pig feces to be used as additives in pelleted feeding", Res. Microbiol., 157, 792-801 (2006).

14. M. Gotteland, M. J. Cires, C. Carvallo, N. Vega, M. A. Ramirez, P. Morales, et al., "Probiotic screening and safety evaluation of Lactobacillus strains from plants, artisanal goat cheese, human stools, and breast milk", J. Med. Food., 17, 487-495 (2014).

15. H. Ekmekci, B. Aslim and S. Ozturk, "Characterization of vaginal lactobacilli coaggregation ability with Escherichia coli", Microbiol. Immunol., 53, 59-65 (2009).

16. R. Campana, S. van Hemert and W. Baffone, "Strain-specific probiotic properties of lactic acid bacteria and their interference with human intestinal pathogens invasion", Gut. Pathog., 9, 12 (2017). 
17. H. Abouloifa, Y. Rokni, R. Bellaouchi, N. Ghabbour, S. Karboune, M. Brasca, et al., "Characterization of probiotic properties of antifungal Lactobacillus strains isolated from traditional fermenting green olives", Probiotics Antimicrob. Proteins, 12, 683696 (2020).

18. J. Ji and H. Yang, "In-vitro effects of Lactobacillus plantarum LN66 and antibiotics used alone or in combination on Helicobacter pylori mature biofilm", Microorganisms, 9, 424 (2021).

19. European Food Safety Authority (EFSA), "Guidance on the Characterisation of Microorganisms Used as Feed Additives or as Production Organisms", (2018).

20. A. M. Martín-Platero, E. Valdivia, M. Maqueda and M. Martínez-Bueno, "Fast, convenient, and economical method for isolating genomic DNA from lactic acid bacteria using a modification of the protein "salting-out" procedure", Anal. Biochem., 366, 102-104 (2007).

21. L. I. I. Ouoba, V. Lei and L. B. Jensen, "Resistance of potential probiotic lactic acid bacteria and bifidobacteria of African and European origin to antimicrobials: Determination and transferability of the resistance genes to other bacteria", Int. J. Food Microbiol., 121, 217-224 (2008).

22. C. Garofalo, C. Vignaroli, G. Zandri, L. Aquilanti, D. Bordoni, A. Osimani, et al., "Direct detection of antibiotic resistance genes in specimens of chicken and pork meat", Int. J. Food. Microbiol., 113, 7583 (2007).

23. Y. Shao, W. Zhang, H. Guo, L. Pan, H. Zhang and T. Sun, "Comparative studies on antibiotic resistance in Lactobacillus casei and Lactobacillus plantarum", Food Control, 50, 250-258 (2015).

24. T. A. Melo, T. F. Dos Santos, M. E. de Almeida, L. A. Junior, E. F. Andrade, R. P. Rezende, et al., "Inhibition of Staphylococcus aureus biofilm by Lactobacillus isolated from fine cocoa", BMC Microbiology, 16, 250 (2016).

25. R. Somashekaraiah, B. Shruthi, B. V. Deepthi and M. Y. Sreenivasa, "Probiotic properties of lactic acid bacteria isolated from neera: A naturally fermenting coconut palm nectar", Front Microbiol., 10, 1382 (2019).
26. H. F. Chamber and M. A. Sande, "Antimicrobial Agents: General considerations", In J. G. Hardman and L. E. Limbird (Eds.), The Pharmacological Basis of Therapeutics, $9^{\text {th }}$ Edn. McGrawHill, 1996, pp. 1029-1056.

27. X. Cui, Y. Shi, S. Gu, X. Yan, H. Chen and J. Ge, "Antibacterial and antibiofilm activity of lactic acid bacteria isolated from traditional artisanal milk cheese from northeast China against enteropathogenic bacteria", Probiotics Antimicrob. Proteins, 10, 601-610 (2018).

28. J. Zheng, S. Wittouck, E. Salvetti, C. Franz, H. M. B. Harris, P. Mattarelli, et al., "A taxonomic note on the genus Lactobacillus: Description of 23 novel genera, emended description of the genus Lactobacillus Beijerinck 1901, and union of Lactobacillaceae and Leuconostocaceae", Int. J. Syst. Evol. Microbiol., 70, 2782-2858 (2020).

29. P. Sornplang and S. Piyadeatsoontorn, "Probiotic isolates from unconventional sources: A review", J. Anim. Sci. Technol., 58, 26 (2016).

30. A. Pino, E. Bartolo, C. Caggia, A. Cianci and C. L. Randazzo, "Detection of vaginal lactobacilli as probiotic candidates", $\mathbf{S c i}$. Rep., 9, 3355 (2019).

31. A. Fessard and F. Remize, "Why are Weissella spp. not used as commercial starter cultures for food fermentation?", Fermentation, 3, 38 (2017).

32. T. Ghosh, A. Beniwal, A. Semwal and N. K. Navani, "Mechanistic insights into probiotic properties of lactic acid bacteria associated with ethnic fermented dairy products", Front Microbiol., 10, 502 (2019).

33. Y. Nami, R. V. Bakhshayesh, H. M. Jalaly, H. Lotfi, S. Eslami and M. A. Hejazi, "Probiotic properties of Enterococcus isolated from artisanal dairy products", Front Microbiol., 10, 300 (2019).

34. F. Ben Taheur, B. Kouidhi, K. Fdhila, H. Elabed, R. Ben Slama, K. Mahdouani, et al., "Anti-bacterial and anti-biofilm activity of probiotic bacteria against oral pathogens", Microb. Pathog., 97, 213-220 (2016). 
35. S. Y. Ng, S. S. Koon, B. S. Padam and F. Y. Chye, "Evaluation of probiotic potential of lactic acid bacteria isolated from traditional Malaysian fermented Bambangan (Mangifera pajang)", CyTA Journal of Food, 13, 563-572 (2015).

36. L. Ruiz, A. Margolles and B. Sanchez, "Bile resistance mechanisms in Lactobacillus and Bifidobacterium", Front Microbiol., 4, 396 (2013).

37. K. Banwo, A. Abiodun Sanni and H. Tan, "Functional properties of Pediococcus species isolated from traditional fermented cereal gruel and milk in Nigeria", Food Biotechnology, 27, 14-38 (2013).

38. S. Ruiz-Moyano, A. Martin, M. J. Benito, F. P. Nevado and M. de Guia Cordoba, "Screening of lactic acid bacteria and bifidobacteria for potential probiotic use in Iberian dry fermented sausages", Meat. Sci., 80, 715-721 (2008).

39. C. Guan, X. Chen, X. Jiang, R. Zhao, Y. Yuan, D. Chen, et al., "In-vitro studies of adhesion properties of six lactic acid bacteria isolated from the longevous population of China", RSC Adv., 10, 24234-24240 (2020).

40. H. Xu, H. S. Jeong, H. Y. Lee and J. Ahn, "Assessment of cell surface properties and adhesion potential of selected probiotic strains", Lett. Appl. Microbiol., 49, 434442 (2009).

41. G. Krausova, I. Hyrslova and I. Hynstova, "In-vitro evaluation of adhesion capacity, hydrophobicity, and auto-aggregation of newly isolated potential probiotic strains", Fermentation, 5, 100 (2019).

42. D. M. Saulnier, J. K. Spinler, G. R. Gibson and J. Versalovic, "Mechanisms of probiosis and prebiosis: Considerations for enhanced functional foods", Curr. Opin. Biotechnol., 20,135-141 (2009).

43. R. H. Bassyouni, W. S. Abdel-all, M. G. Fadl, S. Abdel-all and Z. Kamel, "Characterization of lactic acid bacteria isolated from dairy products in Egypt as a probiotic", Life Science Journal, 9, 29242933 (2012).

44. R. H. Bassyouni, W. S. Abdel-all, M. G. Fadl, S. Abdel-all and Z. Kamel, "Characterization of lactic acid bacteria isolated from dairy products in Egypt as a probiotic", Life Science Journal, 9, 29242933 (2012).

45. G. Tadesse, E. Ephraim and M. Ashenafi, "Assessment of the antimicrobial activity of lactic acid bacteria isolated from Borde and Shamita, traditional Ethiopian fermented beverages, on some foodborne pathogens and effect of growth medium on the inhibitory activity", Internet Journal of Food Safety, 5, 13-20 (2005).

46. M. Gueimonde, B. Sanchez, C. G. de los Reyes-Gavilán and A. Margolles, "Antibiotic resistance in probiotic bacteria", Front Microbiol., 4, 202 (2013).

47. A. S. Hummel, C. Hertel, W. H. Holzapfel and C. M. Franz, "Antibiotic resistances of starter and probiotic strains of lactic acid bacteria", Appl. Environ. Microbiol., 73, 730-739 (2007).

48. F. S. Ali, G. Zayed, O. A. O. Saad and S. A. H. Gharib, "Antimicrobial activity and probiotic properties of lactic acid bacteria iolated fom taditional frmented diry poducts", J. Mod. Res., 2, 40-48 (2020).

49. H. Guo, L. Pan, L. Li, J. Lu, L. Kwok, B. Menghe, et al., "Characterization of antibiotic resistance genes from Lactobacillus isolated from traditional dairy products", J. Food Sci., 82, 724-730 (2017).

50. A. T. de Paula, A. B. Jeronymo-Ceneviva, L. F. Silva, S. D. Todorov, B. D. Franco, Y. Choiset, et al., "Leuconostoc mesenteroides SJRP55: A bacteriocinogenic strain isolated from Brazilian water buffalo mozzarella cheese", Probiotics Antimicrob. Proteins., 6, 186197 (2014).

51. I. Moreno, E. T. G. Marasca, P. de Sa, J. de SouzaMoitinho, M. G. Marquezini, M. R. C. Alves, et al., "Evaluation of probiotic potential of bacteriocinogenic lactic acid bacteria strains isolated from meat products", Probiotics Antimicrob. Proteins, 10, $762-774$ (2018).

52. M. A. El-Mokhtar, K. M. Hassanein, A. S. Ahmed, G. F. Gad, M. M. Amin and O. F. Hassanein, "Antagonistic Activities of Cell-Free Supernatants of Lactobacilli Against Extended-Spectrum $\beta$-Lactamase Producing Klebsiella pneumoniae and 
Pseudomonas aeruginosa." Infection and Drug Resistance, 13, 543-552 (2020).

53. L. De Vuyst, L. Makras, L. Avonts, H. Holo, Q. Yi, A. Servin, et al., "Antimicrobial potential of probiotic or potentially probiotic lactic acid bacteria, the first results of the international European research project PROPATH of the PROEUHEALTH cluster", Microb. Ecol. Health Dis., 16, 125-130 (2004).

54. C. C. Chen, C. C. Lai, H. L. Huang, W. Y. Huang, H. S. Toh, T. C. Weng, et al., "Antimicrobial activity of Lactobacillus species against carbapenem-resistant
Enterobacteriaceae", Front Microbiol., 10, 789 (2019).

55. H. Mathur, D. Field, M. C. Rea, P. D. Cotter, C. Hill and R. P. Ross, "Bacteriocin-antimicrobial synergy: A medical and food perspective", Front Microbiol., 8, 1205 (2017).

56. A. Barzegari, K. Kheyrolahzadeh, S. M. Hosseiniyan Khatibi, S. Sharifi, M. Y. Memar, S. Zununi Vahed, "The battle of probiotics and their derivatives against biofilms", Infect. Drug Resist., 13, 659672 (2020). 


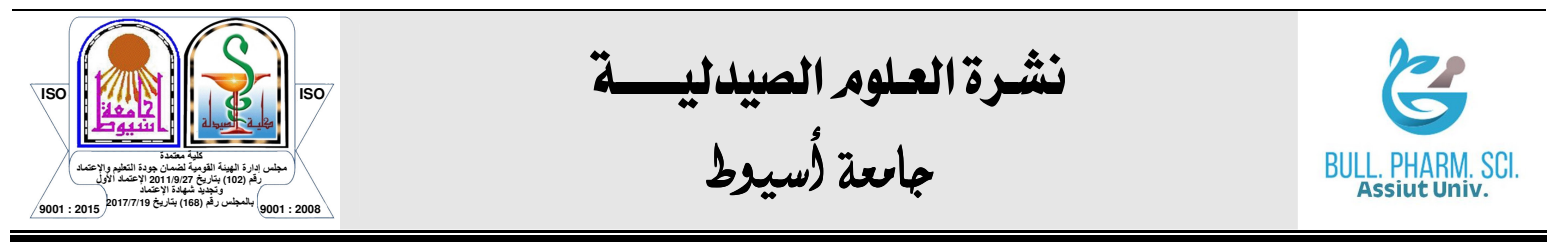

\title{
فحص إمكانات عزلات مختارة من سلالات حمض اللبنيك المعزولة من اصول طبيعية

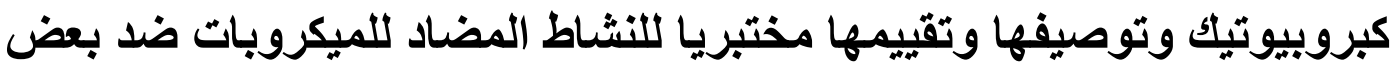 مسبيات الأمراض البشرية
}

\author{
عزة زكريا - ميرقت قاسم - منى الفار - ايفا ادوارد \\ قسم الميكروبيولوجيا والمناعة ، كلية الصيدلة ، جامعة الإسكندرية ، الإسكندرية ، مصر
}

أصبحت بكتيريا البروبيوتيك شائعة مؤخرًا لآثار ها المفيدة المتعلقة بالصحة. في هذه الدر اسـة تم

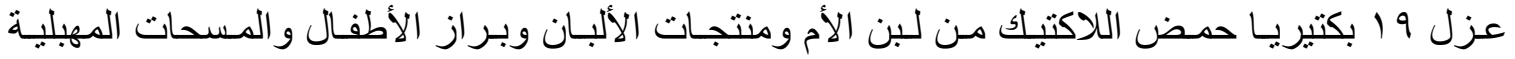

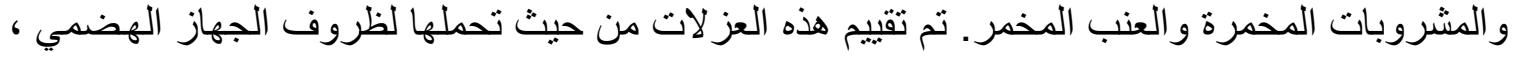

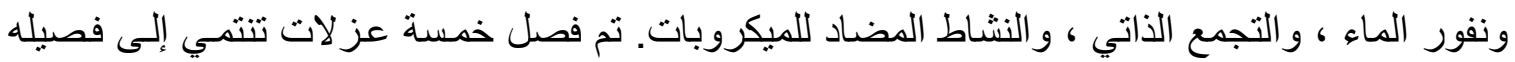

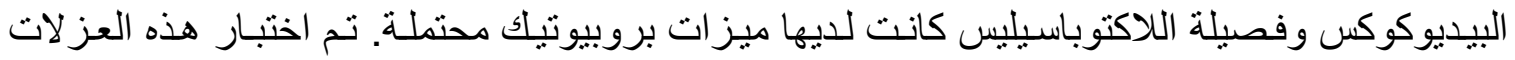

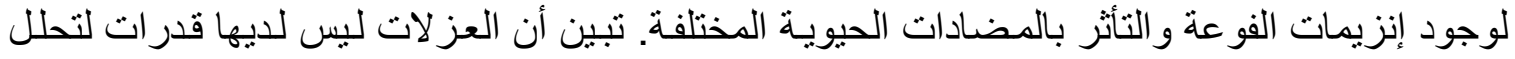

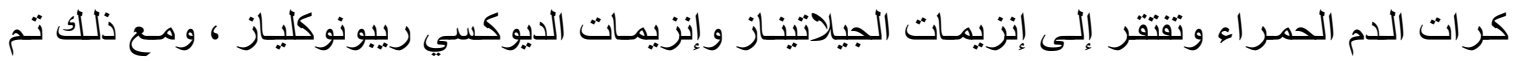

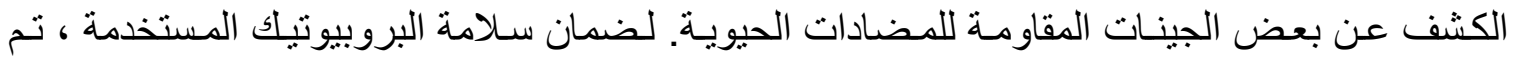

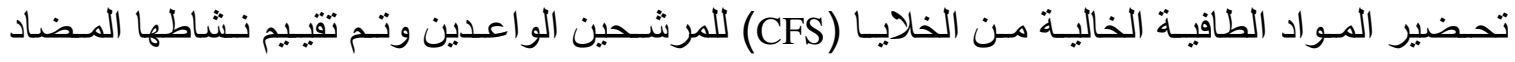

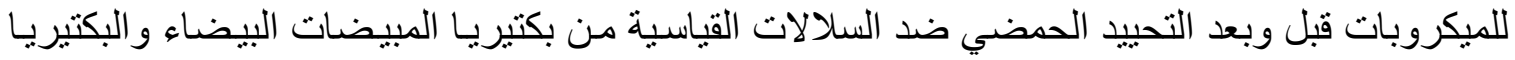

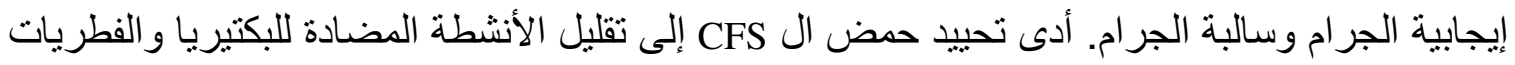

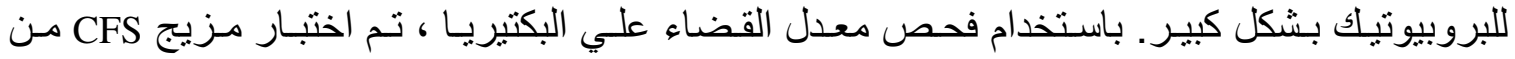

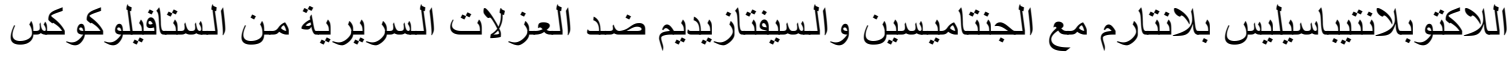
اوريوس والايشريشيا كو لاي تم الحصول على انخفاض ملحوظ في عدد اللوغاريتمـات للناجين باستخدام

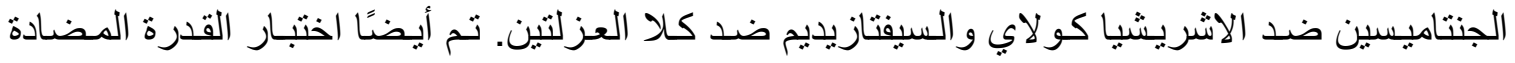

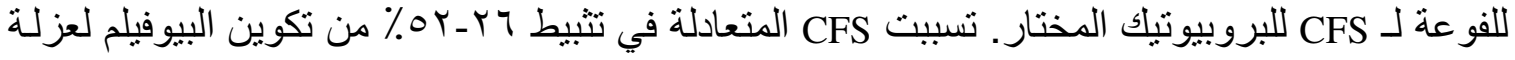

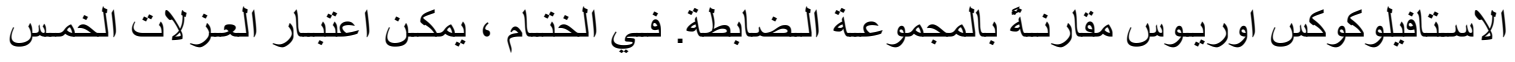

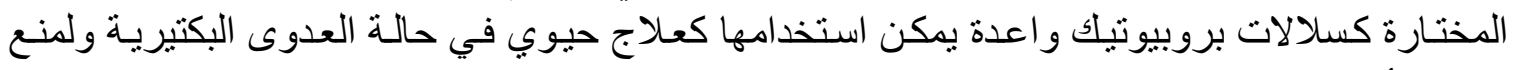
تكون الأغشية الحيوية. 